\title{
Disease propagation in amyotrophic lateral sclerosis (ALS): an interplay between genetics and environment
}

\author{
Sarah Schram, Jeffrey A. Loeb* and Fei Song ${ }^{*}$ (D)
}

\begin{abstract}
Amyotrophic lateral sclerosis (ALS) is a progressive, fatal disease affecting the neuromuscular system. While there have been a number of important genetic discoveries, there are no therapeutics capable of stopping its insidious progression. Lessons from clinical histories reveal that ALS can start focally at a single limb, but then segmentally spread up and down the spinal cord as well as in the motor cortex and cortex of frontal and temporal lobes until respiratory muscles fail. With or without a clear genetic etiology, often there is no explanation as to why it starts in one region of the body versus another. Similarly, once the disease starts the mechanisms by which the neurodegenerative process spreads are not known. Here, we summarize recent work in animal models that support the hypothesis that critical environmental contributions, such as a nerve injury, can initiate the disease process. We also propose that pathological axoglial signaling by the glial growth factor neuregulin-1 leads to the slow propagation of neuroinflammation resulting in neurodegeneration up and down the spinal cord and that locally applied drugs that block neuregulin-1 signaling could slow or halt the spread of disease.
\end{abstract}

Keywords: Nerve injury-mediated neuroinflammation, Neuronal-glial communication through glial growth factor neuregulin, Inhibition of neuregulin-mediated inflammation

\section{Introduction}

Amyotrophic lateral sclerosis (ALS) is a neurodegenerative disease characterized by spreading paralysis which can originate in any part of the body. The disease is poorly understood with no effective therapeutics and an average survival time of less than 5 years according to the ALS association. Given the wide variations in genetic links and variable clinical presentations even with the same genetic mutations, environmental contributions are likely to be very important in ALS [1]. Veterans and athletes have been shown to be at an increased risk of developing the disease, suggesting injury may act as an environmental trigger [2-4]. Here, we discuss potential mechanisms that contribute to disease progression, the

* Correspondence: jaloeb@uic.edu; feisong@uic.edu

Department of Neurology and Rehabilitation, University of Illinois at Chicago, NPI North Bldg., Room 657, M/C 796, 912 S. Wood Street, Chicago, IL 60612, USA

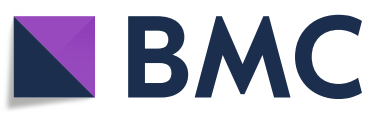

possibility of injury as an instigating event, and the potential role of the growth factor neuregulin in disease spread.

\section{Environmental contributions}

It has long been suggested that environmental factors such as lead, pesticides, trauma, and physical activity can act as triggers for ALS [5]. Population studies show that the disease is $2-3$ times more common in varsity and professional athletes and veterans, even without combat experience [2-4, 6-8]. In fact, heightened physical activity in general appears to be correlated with a greater risk of disease [4, 9]. One potential explanation is that focal nerve injury could trigger disease onset in a specific limb. Head trauma may also play a role based on both animal and patient studies $[10,11]$. Despite the multiple case studies and larger epidemiological studies suggesting a link, other studies have shown conflicting results

(c) The Author(s). 2020 Open Access This article is licensed under a Creative Commons Attribution 4.0 International License, which permits use, sharing, adaptation, distribution and reproduction in any medium or format, as long as you give appropriate credit to the original author(s) and the source, provide a link to the Creative Commons licence, and indicate if changes were made. The images or other third party material in this article are included in the article's Creative Commons licence, unless indicated otherwise in a credit line to the material. If material is not included in the article's Creative Commons licence and your intended use is not permitted by statutory regulation or exceeds the permitted use, you will need to obtain permission directly from the copyright holder. To view a copy of this licence, visit http://creativecommons.org/licenses/by/4.0/ The Creative Commons Public Domain Dedication waiver (http://creativecommons.org/publicdomain/zero/1.0/) applies to the data made available in this article, unless otherwise stated in a credit line to the data. 
$[12,13]$. This indicates that any role injury may play is complicated and probably includes a mosaic of other predispositions including genetic susceptibility, gender, age, type, and location of injury. Furthermore, a study in Denmark, showed that timing of the injury (more than 5 years prior to diagnosis) and age of injury (before age 55) is crucial for the degree of increased risk and may explain some confounding results in prior studies [14]. Unfortunately, without the availability of definite biomarkers, the contribution of injury remains challenging to prove.

\section{Animal models combining nerve injury with genetics}

Animal models have been useful in investigating the effects of injury on disease development and progression in ALS models. A study by Sharp and colleagues demonstrated that in the mutant superoxide dismutase 1 (SOD1)-expressing mouse, a sciatic nerve crush induced changes in fatigue-resistance characteristics and muscle fiber type in the extensor digitorum longus muscle prematurely at times when deficits are not normally seen. This injury also increased motor neuron loss in the ventral horn of the spinal cord [15]. Another study showed similar findings following facial motor neuron damage [16].

The mutant SOD1-expressing rat has also been used in similar experiments. Unlike mice, rats with SOD1 mutations have shown variability in the site of symptom onset. Whereas mice consistently present with initial lower limb weakness, rats can present with lower limb or upper limb involvement [17]. A recent study by Schram et al. [18] investigated the effects of a sciatic nerve crush on disease progression and inflammation in the SOD1 rat. A single, unilateral crush lesion of the sciatic nerve at 10 weeks of age, prior to disease onset, hastened functional decline and shortened survival compared to uninjured SOD1 littermates [18]. Whereas control animals regained full motor function within a few weeks following injury, the SOD1 rats never recovered and developed weakness on the contralateral leg well before other, non-injured SOD1 rats. This suggests that the single nerve injury initiated an earlier disease onset and promoted the local spread of disease. Quantitative histological studies on the spinal cord at different time points coinciding with decreases in motor function demonstrated a markedly increased and prolonged microglial inflammatory response followed by earlier and more pronounced astrocytic recruitment in the SOD1 animal versus controls (Fig. 1). This localized, increased inflammatory response was associated with a significant reduction in motor neuron synaptic connectivity that could explain how the heightened, injuryinduced inflammatory response leads to earlier motor neuron degeneration [18].

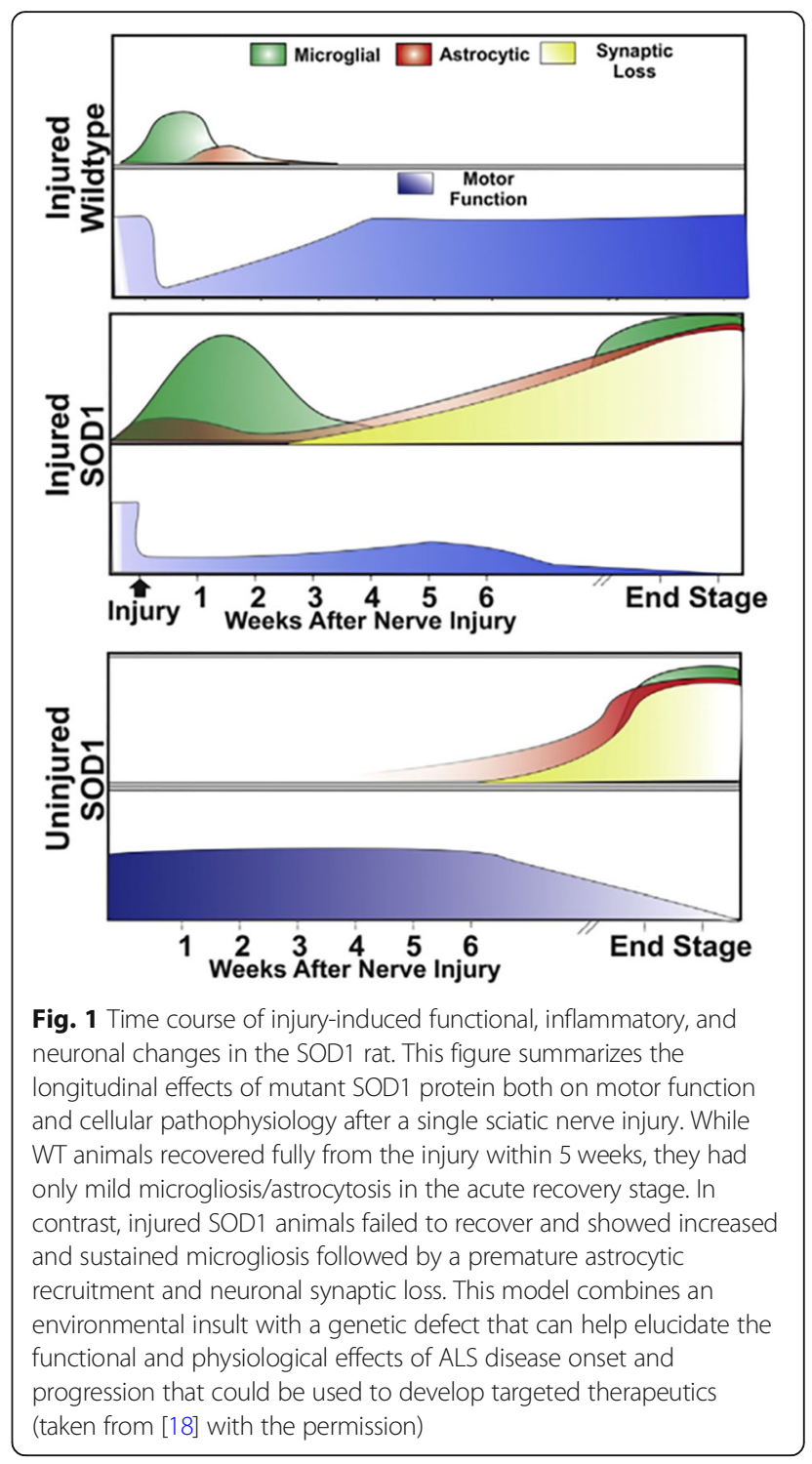

Some of these effects may be mediated by activity, as another study showed hyperstimulation of the phrenic nerve via implanted electrode in the SOD1 rat showed more rapid motor neuron loss, denervation of the diaphragm muscle, and decreased life span [19]. Interestingly, this stimulation also led to spread of diseaseassociated weakness to the forelimbs, altering disease progression from that typically seen in SOD1 rodents. In contrast, other studies show a paradoxical effect, where a tibial nerve crush injury in an SOD1 rat at the L5 spinal nerve or distal sciatic nerve led to an increase in motor neuron survival in a subset of motor neurons following disease onset $[20,21]$. However, these studies showed no effect on time to disease onset, duration, or survival. 


\section{Inflammatory response to injury as a driver of neurodegeneration}

The normal injury response is composed of a series of tightly regulated cellular and molecular processes involving numerous signaling cascades designed to aid recovery [22]. Additionally, the degree and duration of the injury response can vary based on severity and location. In general, there are two phases of injury recovery, acute and chronic, and each is associated with changes in gene transcription and translation in a variety of cell types. As part of the injury repair process, microglia are thought to strip synaptic connections, as observed in the above nerve injury model in SOD1 rats [18]. Microglia are also known to modify synaptic circuits during development, and more recent studies show a similar process in adult neurogenesis [23, 24]. As part of this experience-dependent modification system, there is extensive contact between microglial processes and synapses. It has been proposed that this contact leads to synaptic rewiring and removal following traumatic events, such as stroke or axonal damage, in which microglial contact increases and synaptic activity decreases [25-27]. Furthermore, microglia express C1q, a major component of the complement system and inducer of phagocytosis. C1q-tagged synapses have been described in the brain and suggested to be a mechanism for synaptic removal $[28,29]$.

In ALS, microglia appear to play a highly dynamic role as their phenotypic expression changes as the disease progresses. Microglia secrete neuroprotective factors such as IL-10 in pre-symptomatic stages, then adopt a more detrimental state as disease onset occurs and secrete activators associated with inflammation and cell death [30-32]. In vitro studies of primary microglia isolated from neonatal SOD1 mice show an increased response to LPS in terms of cell surface protein expression and changes in size/morphology [33]. Relatedly, microglia collected from the spinal cord of the SOD1 (G93A) rats at three different points in disease progression (presymptomatic, symptom onset, and end-stage) show different activation patterns, suggesting an active role in disease progression [34]. Microglia carrying mutations are also shown to exacerbate and speed up disease progression, while WT microglia promote survival [35-37]. This may be due to heightened inflammatory activity of mutant microglia as well as a pathological response to the presence of misfolded protein [38-40].

Consistently, co-cultures of microglia with motor neurons have shown that microglia can directly lead to motor neuron death and require nuclear factor kappalight-chain-enhancer of activated B cells (NF- $\mathrm{kB}$ ) signaling [40]. Together, these studies highlight a crucial role of microglial-dependent inflammation in disease onset and progression and highlight the potential importance of the augmented inflammatory responses observed to occur after injury.

One issue that continues to plague ALS research is the lack of effective therapeutic translation from animal models to patients. Key to improving this track record is identifying shared targets between animal models and the human disorder. Patient studies confirm the presence of abnormal inflammation and microglial activation in post-mortem human tissues [41, 42]. This is in addition to experiments that detected inflammation in the cortex of living ALS patients with positron emission tomography (PET) [43]. Therapeutic targeting of nervous system inflammation continues to be an attractive strategy for ALS treatment, despite having not yet been proven effective in human clinical trials [31]. It is increasingly clear that understanding how and when to reduce inflammatory activation will be important for the treatment of this and many other neurological diseases $[34,44]$.

\section{Neuron-glia signaling as a mechanism of disease spread}

Neurons have numerous signaling mechanisms to communicate with surrounding glia and other cells. One such signaling factor well studied in development is neuregulin-1 (NRG1). In the nervous system, NRG1 is a predominantly neuron-derived growth and differentiation factor that signals from neurons to surrounding cells through activation of the epidermal growth factor (EGF)-family of tyrosine kinase receptors human epidermal growth factor receptor (HER)2-4 [45-51]. NRG1 supports neuromuscular junction formation during development and has been implicated in a number of disease conditions [52-54]. NRG1, previously called glial growth factor, is a potent mitogen for glial cells and plays a role in nerve injury repair [55] with increased HERs and NRG1 in the initial stages following injury $[56,57]$. Specifically, NRG1 expression and release increases during re-innervation of target muscles after injury and promotes remyelination of spinal motor neurons [58].

However, prolonged or excessive NRG1 signaling can be problematic. For example, after peripheral nerve injury in animal models of chronic pain, NRG1 from dorsal root ganglia neurons is released into the spinal cord leading to microglial activation. Blocking NRG1 after nerve injury using a number of agents dramatically reduces microglial activation and the development of chronic pain [59]. This pathological inflammation is thought to contribute to the development of chronic pain through microglia-mediated synaptic rewiring in the dorsal horn of the spinal cord [59, 60]. These observations have led to the exploration of NRG1's possible role in promoting excessive inflammation in the ventral 
horn of the spinal cord in ALS. Because of its ability to remain localized within the extracellular matrix through a unique heparin-binding domain, NRG1 accumulation could mediate the slow spread of neuroinflammation and possibly disease spread up or down the spinal cord in ALS.

\section{Neuregulin signaling is increased in ALS and is a potential therapeutic target}

In ALS, aberrant NRG1 signaling has been shown in human tissues and animal models [42, 61-63]. Specifically, phosphorylated (activated) NRG1 receptors have been observed on activated microglia in the spinal cords of both ALS patients and animal models $[41,42]$. This activation, just as in the chronic pain models discussed above, could lead to enhanced inflammation leading to motor neuron damage and death. Neuronal degeneration leads to more NRG1 release producing further microglial activation hence propagating the neurodegenerative process up and down the spinal cord (Fig. 2). Consistently, a highly selective NRG1 antagonist was shown to decrease microglial activation, reduce motor neuron loss, delay disease onset, and prolong survival in the SOD1 G93A mouse model [61]. This antagonist is a humanized fusion protein consisting of the extracellular domain of the HER4 NRG1 receptor and NRG1's own heparin-binding domain, which, unlike other biologics such as antibodies, allows the drug to penetrate the CNS and directs to the same sites that NRG1 goes [64]. In addition to being humanized and producing no toxic side effects, a key advantage of using this fusion protein to block neuroinflammation is that it can be delivered directly to the brain through the cerebral spinal fluid [60]. Direct CNS delivery has a key advantage of reducing peripheral, off-target effects that have led to significant side effect from other anti-inflammatory drugs given systemically [63]. These features make it an attractive and potentially translatable treatment to stop or slow disease progression in ALS patients.

Delivery of the NRG1 antagonist directly into the central nervous system (CNS) is important in light of other findings suggesting that NRG1 may still be needed to maintain neuromuscular junctions and can be protective in ALS animal models [65-67]. Lasiene et al. [65] reported that viral-mediated delivery of type I-NRG1 (soluble form of NRG1) to the spinal cord had no beneficial effect on disease onset and survival in SOD1 G93A mice. Interestingly, a similar study examining the effects of overexpressing type III-NRG1 in the spinal cord through viral delivery resulted in preserved neuromuscular function of the hindlimbs, improved locomotor performance, and increased numbers of surviving motor neurons along with reduced glial reactivity, but only in female mice [68]. However, viral-mediated delivery of type IIINRG1 (membrane-bound form of NRG1) to the spinal cord restored C-bouton puncta and extended survival in SOD1 mice with no effect on disease onset, suggesting supplementation of membrane-bound NRG1 confers neuroprotection in motor neuron disease [65]. While we similarly showed that intraventricular delivery of NRG1 had no effects on disease onset and survival in SOD1 G93A mice, blocking endogenous NRG1 with an intraventricular antagonist was protective [61]. Taken together, the mode and location of delivery appears to be critical in order to block NRG1 within the CNS, while allowing its normal function in the peripheral nervous system (as highlighted in Fig. 2), to reduce neuroinflammation and neurodegeneration in ALS.

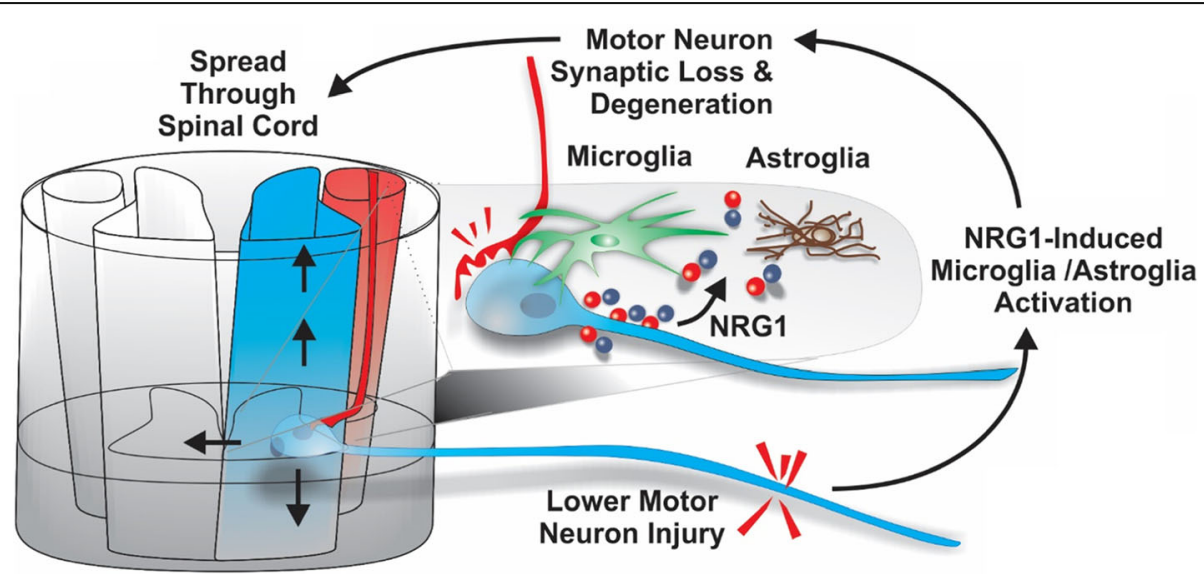

Fig. 2 Proposed mechanism of nerve-injury-induced activation of neuregulin-1 leads to spread of disease. In the presence of mutant SOD1 protein, nerve injury produces a heightened, NRG-induced inflammatory response leading to a permanent loss of synapses that spreads up and down the spinal cord and resulting in progressive neurodegeneration. Results summarized in Fig. 1 suggest that this inflammatory response starts with microglia followed by a second wave of astroglial reactivity that correlates with a significant loss of motor neuron synaptic inputs 


\section{Conclusions}

In summary, inhibition of NRG1-mediated neuroinflammation could prevent synaptic stripping and other toxic effects of chronic inflammation leading to disease progression in ALS, regardless of the underlying genetics. Our studies in the SOD1 G93A mouse model treated with a NRG antagonist support this theory and show an increase in survival [61]. New animal models are needed that better mimic disease progression in humans. Models that use nerve injury to initiate focal and early disease onset could be used to test therapeutics targeting disease progression in a number of genetic models. Another critical area of research needed to advance therapeutics that focus on disease progression will be the identification of reliable and non-invasive biomarkers of disease progression. These key facets will enable a better understanding of disease pathology and paradigm shifts in treatment, ultimately resulting in therapies truly capable of providing hope for patients.

\section{Abbreviations \\ ALS: Amyotrophic lateral sclerosis; SOD1: Superoxide dismutase 1; NF- KB: Nuclear factor kappa-light-chain-enhancer of activated B cells; PET: Positron emission tomography; NRG1: Neuregulin-1; EGF: Epidermal growth factor; HER: Human epidermal growth factor receptor; CNS: Central nervous system}

\section{Acknowledgements}

This work was supported in part by the Patrick Grange Memorial Foundation.

\section{Authors' contributions}

SS researched the literature and drafted the manuscript. JAL and FS critically reviewed and edited the work. All authors read and approved the final manuscript.

\section{Funding}

Not applicable.

\section{Availability of data and materials \\ Not applicable.}

\section{Ethics approval and consent to participate}

Not applicable.

\section{Consent for publication}

Not applicable.

\section{Competing interests}

The authors (JAL and FS) have intellectual property on the use of the neuregulin antagonist fusion protein to treat neurodegenerative diseases.

Received: 26 March 2020 Accepted: 19 May 2020

Published online: 06 June 2020

\section{References}

1. Chen S, Sayana P, Zhang X, Lecorresponding W. Genetics of amyotrophic lateral sclerosis: an update. Mol Neurodegener. 2013;8:28.

2. Horner RD, Kamins KG, Feussner JR, Grambow SC, Hoff-Lindquist J, Harati $Y$, Mitsumoto H, Pascuzzi R, Spencer PS, Tim R, Howard D, Smith TC, Ryan MAK, Coffman CJ, Kasarskis EJ. Occurrence of amyotrophic lateral sclerosis among Gulf War veterans. Neurology. 2003;61:742-9.

3. Ingre C, Roos PM, Piehl F, Kamel F, Fang F. Risk factors for amyotrophic lateral sclerosis. Clin Epidemiol. 2015;7:181-93.

4. Visser AE, Rooney JPK, D'Ovidio F, Westeneng HJ, Vermeulen $\mathrm{RCH}$, Beghi $\mathrm{E}_{\text {, }}$ Chio A, Logroscino G, Hardiman O, Veldink JH, van den Berg LH. Euro-
MOTOR consortium: Multicentre, cross-cultural, population-based, casecontrol study of physical activity as risk factor for amyotrophic lateral sclerosis. J Neurol Neurosurg Psychiatry. 2018;89:797-803.

5. Oskarsson B, Horton DK, Mitsumoto H. Potential environmental factors in amyotrophic lateral sclerosis. Neurol Clin. 2015;33:877-88.

6. Scarneas N, Shih T, Stern Y, Ottman R, Rowland LP. Premorbid weight, body mass, and varsity athletics in ALS. Neurology. 2002;59:773-5.

7. Chio A. Mortality trends in ALS: an increasingly intricate puzzle. Lancet Neurol. 2005;4:453-4.

8. Guidetti D, Bondavalli M, Sabadini R, Marcello N, Vinceti M, Cavalletti S, Marbini A, Gemignani F, Colombo A, Ferrari A, Vivoli G, Solimè F. Epidemiological survey of amyotrophic lateral sclerosis in the province of Reggio Emilia, Italy: influence of environmental exposure to lead. Neuroepidemiology. 1996;15:301-12.

9. Eaglehouse YL, Talbott EO, Chang Y, Kuller LH. Participation in physical activity and risk for amyotrophic lateral sclerosis mortality among postmenopausal women. JAMA Neurol. 2016;73:329-36.

10. Chen H, Richard M, Sandler DP, Umbach DM, Kamel F. Head injury and amyotrophic lateral sclerosis. Am J Epidemiol. 2007;166:810-6.

11. Moszczynski AJ, Strong W, Xu K, McKee A, Brown A, Strong MJ. Pathologic Thr175tau phosphorylation in CTE and CTE with ALS. Neurology. 2018;90: 380-7.

12. Gallo V, Vanacore N, Bueno-de-Mesquita HB, Vermeulen $R$, Brayne C, Pearce N, Wark PA, Ward HA, Ferrari P, Jenab M, Andersen PM, Wennberg P, Wareham N, Katzke V, Kaaks R, Weiderpass E, Peeters PH, Mattiello A, Pala V, Barricante A, Chirlaque MD, Travier N, Travis RC, Sanchez MJ, PessahRasmussen H, Petersson J, Tjønneland A, Tumino R, Quiros JR, Trichopoulou A, Kyrozis A, Oikonomidou D, Masala G, Sacerdote C, Arriola L, Boeing H, Vigl M, Claver-Chapelon F, Middleton L, Riboli E, Vineis P. Physical activity and risk of amyotrophic lateral sclerosis in a prospective cohort study. Eur J Epidemiol. 2016;31:255-66.

13. Pupillo E, Messina P, Giussani G, Logroscino G, Zoccolella S, Chiò A, Calvo A, Corbo M, Lunetta C, Marin B, Mitchell D, Hardiman O, Rooney J, Stevic Z, Bandettini di Poggio M, Filosto M, Cotelli MS, Perini M, Riva N, Tremolizzo L, Vitelli E, Damiani D, Beghi E: EURALS Consortium. Physical activity and amyotrophic lateral sclerosis: a European population-based case-control study. Ann Neurol 2014:75:708-716.

14. Seals RM, Hansen J, Gredal O, Weisskopf MG. Physical trauma and amyotrophic lateral sclerosis: a population-based study using Danish National Registries. Am J Epidemiol. 2016;183:294-301.

15. Sharp PS, Dick JR, Greensmith L. The effect of peripheral nerve injury on disease progression in the SOD1(G93A) mouse model of amyotrophic lateral sclerosis. Neuroscience. 2005;130:897-910.

16. Mariotti R, Cristino L, Bressan C, Boscolo S, Bentivoglio M. Altered reaction of facial motoneurons to axonal damage in the presymptomatic phase of a murine model of familial amyotrophic lateral sclerosis. Neuroscience. 2002; 115:331-5.

17. Woodruff TM, Costantini KJ, Crane JW, Atkin JD, Monk PN, Taylor SM, Noakes PG. The complement factor C5a contributes to pathology in a rat model of amyotrophic lateral sclerosis. J Immunol. 2008;181:8727-34.

18. Schram S, Chuang D, Schmidt G, Piponov H, Helder C, Kerns J, Gonzalez M, Song F, Loeb JA. Mutant SOD1 prevents normal functional recovery through enhanced glial activation and loss of motor neuron innervation after peripheral nerve injury. Neurobiol Dis. 2019;124:469-78.

19. Lepore AC, Tolmie C, O'Donnell J, Wright MC, Dejea C, Rauck B, Hoke A Ignagni AR, Onders RP, Maragakis NJ. Peripheral hyperstimulation alters site of disease onset and course in SOD1 rats. Neurobiol Dis. 2010;39:252-64.

20. Franz CK, Quach ET, Krudy CA, Federici T, Kliem MA. A conditioning lesion provides selective protection in a rat model of amyotrophic lateral sclerosis. PLOS ONE. 2009;4:e7357.

21. Kong J, Xu Z. Peripheral axotomy slows motoneuron degeneration in a transgenic mouse line expressing mutant SOD1 G93A. J Comp Neurol. 1999; 412:373-80

22. Gadani SP, Walsh JT, Lukens JR, Kipnis J. Dealing with danger in the CNS: the response of the immune system to injury. Neuron. 2015;87:47-62.

23. Wu Y, Dissing-Olesen L, MacVicar BA, Stevens B. Microglia: dynamic mediators of synapse development and plasticity. Trends Immunol. 2015;36: 605-13.

24. Sierra A, Encinas JM, Deudero JJ, et al. Microglia shape adult hippocampal neurogenesis through apoptosis-coupled phagocytosis. Cell Stem Cell. 2010; 7:483-95. 
25. Wake H, Moorhouse AJ, Jinno S, Kohsaka S, Nabekura J. Resting microglia directly monitor the functional state of synapses in vivo and determine the fate of ischemic terminals. J Neurosci. 2009;29:3974-80.

26. Blinzinger K, Krautzberg G. Displacement of synaptic terminals from regenerating motoneurons by microglial cells. Z Zellforsch Mikrosk Anat. 1968;85:145-57.

27. Yamada J, Jinno S. Alterations in neuronal survival and glial reactions after axotomy by ceftriaxone and minocycline in the mouse hypoglossal nucleus. Neurosci Lett. 2011;504:295-300.

28. Hong S, Beja-Glasser VF, Nfonoyim BM, Frouin A, Li S, Ramakrishnan S, Merry KM, Shi Q, Rosenthal A, Barres BA, Lemere CA, Selkoe DJ, Stevens B. Complement and microglia mediate early synapse loss in Alzheimer mouse models. Science. 2016:352:712-6.

29. Stevens B, Allen NJ, Vazquez LE, Howell GR, Christopherson KS, Nouri N, Micheva KD, Mehalow AK, Huberman AD, Stafford B, Sher A, Litke AM, Lambris JD, Smith SJ, John SW, Barres BA. The classical complement cascade mediates CNS synapse elimination. Cell. 2007;131:1164-78.

30. Gravel M, Béland LC, Soucy G, Abdelhamid E, Rahimian R, Gravel C, Kriz J. IL10 controls early microglial phenotypes and disease onset in ALS caused by misfolded superoxide dismutase 1. J Neurosci. 2016;36:1031-48.

31. Geloso MC, Corvino V, Marchese E, Serrano A, Michetti F, D'Ambrosi N. The dual role of microglia in ALS: mechanisms and therapeutic approaches. Front Aging Neurosci. 2017;9:242.

32. Brites D, Vaz AR. Microglia centered pathogenesis in ALS: insights in cell interconnectivity. Front Cell Neurosci. 2014;8:117.

33. Sargsyan SA, Blackburn DJ, Barber SC, Monk PN, Shaw PJ. Mutant SOD1 G93A microglia have an inflammatory phenotype and elevated production of MCP-1. Neuroreport. 2009;20:1450-5.

34. Nikodemova M, Small AL, Smith SM, Mitchell GS, Watters JJ. Spinal but not cortical microglia acquire an atypical phenotype with high VEGF, galectin-3 and osteopontin, and blunted inflammatory responses in ALS rats. Neurobiol Dis. 2014:69:43-53.

35. Boillée S, Yamanaka K, Lobsiger CS, Copeland NG, Jenkins NA, Kassiotis G, Kollias G, Cleveland DW. Onset and progression in inherited ALS determined by motor neurons and microglia. Science. 2006;312(5778):1389-92.

36. Wang L, Deng HX, Grisotti G, Zhai H, Siddique T, Roos RP. Wildtype SOD1 overexpression accelerates disease onset of a G85R SOD1 mouse. Hum Mol Genet. 2009:18:1642-51.

37. Beers DR, Henkel JS, Xiao Q, Zhao W, Wang J, Yen AA, et al. Wildtype microglia extend survival in PU.1 knockout mice with familial amyotrophic lateral sclerosis. Proc Natl Acad Sci USA. 2006;103:16021-6.

38. Zhao W, Beers DR, Bell S, Wang J, Wen S, Baloh RH, Appel SH. TDP-43 activates microglia through NF-KB and NLRP3 inflammasome. Exp Neurol. 2015:273:24-35.

39. D'Ambrosi N, Finocchi P, Apolloni S, Cozzolino M, Ferri A, Padovano V, Pietrini G, Carrì MT, Volonté C. The proinflammatory action of microglial P2 receptors is enhanced in SOD1 models for amyotrophic lateral sclerosis. J Immunol. 2009;183:4648-56.

40. Frakes $A E$, Ferraiuolo L, Haidet-Phillips $A M$, et al. Microglia induce motor neuron death via the classical NF-kB pathway in amyotrophic lateral sclerosis. Neuron. 2014:81:1009-23.

41. Song F, Chiang P, Ravits J, Loeb JA. Activation of microglial neuregulin1 signaling in the corticospinal tracts of ALS patients with upper motor neuron signs. Amyotroph Lateral Scler Frontotemporal Degener. 2014;15:77-83.

42. Song F, Chiang P, Wang J, Ravits J, Loeb JA. Aberrant neuregulin 1 signaling in amyotrophic lateral sclerosis. J Neuropathol Exp Neurol. 2012;71:104-15.

43. Turner MR, Cagnin A, Turkheimer FE, Miller CC, Shaw CE, Brooks DJ, Leigh PN, Banati RB. Evidence of widespread cerebral microglial activation in amyotrophic lateral sclerosis: an [11C](R)-PK11195 positron emission tomography study. Neurobiol Dis. 2004;15:601-9.

44. Chiu IM, Morimoto ET, Goodarzi H, Liao JT, O'Keeffe S, Phatnani HP, Muratet M, Carroll MC, Levy S, Tavazoie S, Myers RM, Maniatis T. A neurodegeneration-specific gene-expression signature of acutely isolated microglia from an amyotrophic lateral sclerosis mouse model. Cell Rep. 2013;4:385-401.

45. Falls DL, Rosen KM, Corfas G, Lane WS, Fischbach GD. ARIA, a protein that stimulates acetylcholine receptor synthesis, is a member of the neu ligand family. Cell. 1993;72:801-15.

46. Ho WH, Armanini MP, Nuijens A, Phillips HS, Osheroff PL. Sensory and motor neuron-derived factor. A novel heregulin variant highly expressed in sensory and motor neurons. J Biol Chem. 1995;270:26722.
47. Goodearl AD, Davis JB, Mistry K, Minghetti L, Otsu M, Waterfield MD, Stroobant P. Purification of multiple forms of glial growth factor. J Biol Chem. 1993;268:18095-102.

48. Marchionni MA, Goodearl ADJ, Chen MS, Bermingham-McDonough O, Kirk C, Hendricks M, Denehy F, Misumi D, Sudhalter J, Kobayashi K, Wroblewski D, Lynch C, Baldassare M, Hiles I, Davis JB, Hsuan JJ, Totty WF, Otsa M, McBury RN, Waterfield MD, Stroobant P. Gwynne D: Glial growth factors are alternatively spliced erbB2 ligands expressed in the nervous system. Nature, 1993:362:312-8

49. Wen D, Peles E, Cupples R, Suggs SV, Bacus SS, Lup Y, Trail G, Hu S, Silbiger SM, Levy RB, Koski RA, Lu HS, Yarden Y. Neu differentiation factor: a transmembrane glycoprotein containing an EGF domain and an immunoglobulin homology unit. Cell. 1992;69:P559-72.

50. Peles E, Bacus SS, Koski RA, Lu HS, Wen D, Ogden SG, Levy RB, Yarden Y. Isolation of the neu/HER-2 stimulatory ligand: a 44 kd glycoprotein that induces differentiation of mammary tumor cells. Cell. 1992;69:205-16.

51. Falls DL. Neuregulins: functions, forms, and signaling strategies. Exp Cell Res. 2003;284:14-30.

52. Esper RM, Pankonin MS, Loeb JA. Neuregulins: versatile growth and differentiation factors in nervous system development and human disease. Brain Res Rev. 2006:51:161-75.

53. Mei L, Nave KA. Neuregulin-ERBB signaling in the nervous system and neuropsychiatric diseases. Neuron. 2014;83:27-49.

54. Mei L, Xiong WC. Neuregulin 1 in neural development, synaptic plasticity and schizophrenia. Nat Rev Neurosci. 2008:9:437-52.

55. Fricker FR, Bennett DL. The role of neuregulin1 in the response to nerve injury. Future Neurol. 2011;6:809-22.

56. Kwon YK, Bhattacharyya A, Alberta JA, Giannobile WV, Cheon K, Stiles CD, Pomeroy SL. Activation of ErbB2 during Wallerian degeneration of sciatic nerve. J Neurosci. 1997:17:8293-9.

57. Carroll SL1, Miller ML, Frohnert PW, Kim SS, Corbett JA. Expression of neuregulins and their putative receptors, ErbB2 and ErbB3, is induced during Wallerian degeneration. J Neurosci. 1997;17:1642-59.

58. Bartus K, Galino J, James ND, Hernandez-Miranda LR, Dawes JM, Fricker FR, Garratt AN, McMahon SB, Ramer MS, Birchmeier C, Bennett DL, Bradbury EJ. Neuregulin-1 controls an endogenous repair mechanism after spinal cord injury. Brain. 2016;139(Pt 5):1394-416.

59. Calvo M, Zhu N, Tsantoulas C, Ma Z, Grist J, Loeb JA, Bennett DL Neuregulin-ErbB signaling promotes microglial proliferation and chemotaxis contributing to microgliosis and pain after peripheral nerve injury. Neurosci. 2010;30:5437-50

60. Calvo M, Zhu N, Tsantoulas C, Ma Z, Grist J, Loeb JA, Bennett DL. Following nerve injury neuregulin-1 drives microglial proliferation and neuropathic pain via the MEK/ERK pathway. Glia. 2011;59:554-68.

61. Liu J, Allender E, Wang J, Simpson EH, Loeb JA, Song F. Slowing disease progression in the SOD1 mouse model by blocking neuregulin-induced microglial activation. Neurobiol Dis. 2018;111:118-26.

62. Takahashi Y, Fukuda Y, Yoshimura J, et al. ERBB4 mutations that disrupt the neuregulin-ErbB4 pathway cause amyotrophic lateral sclerosis type 19. Am J Hum Genet. 2013;93:900-5

63. Arbour D, Vande Velde C, Robitaille R. New perspectives on amyotrophic lateral sclerosis: the role of glial cells at the neuromuscular junction. J Physiol. 2017;595:647-61.

64. Ma Z, Li Q, An H, Pankonin MS, Wang J, Loeb JA. Targeting human epidermal growth factor receptor signaling with the neuregulin's heparinbinding domain. J Biol Chem. 2009;284:32108-15.

65. Lasiene J, Komine O, Fujimori-Tonou N, Powers B, Endo F, Watanabe S, Shijie J, Ravits J, Horner P, Misawa H, Yamanaka K. Neuregulin 1 confers neuroprotection in SOD1-linked amyotrophic lateral sclerosis mice via restoration of C-boutons of spinal motor neurons. Acta Neuropathologica Communications. 2016:4:15

66. Gallart-Palau X, Tarabal O, Casanovas A, Sabado J, Correa FJ, Hereu M, Piedrafita L, Caldero J, Esquerda JE. Neuregulin-1 is concentrated in the postsynaptic subsurface cistern of C-bouton inputs to alphamotoneurons and altered during motoneuron diseases. FASEB J. 2014; 28:618-3632.

67. Mancuso R, Martinez-Muriana A, Leiva T, Gregorio D, Ariza L, Morell M, Esteban-Perez J, Garcia-Redondo A, Calvo AC, Atencia-Cibreiro G, Corfas G, Osta R, Bosch A, Navarro X. Neuregulin-1 promotes functional improvement by enhancing collateral sprouting in SOD1(G93A) ALS mice and after partial muscle denervation. Neurobiol Dis. 2016;95:168-78. 
68. Mòdol-Caballero G, García-Lareu B, Verdés S, Ariza L, Sánchez-Brualla I, Brocard F, Bosch A, Navarro X, Herrando-Grabulosa M. Therapeutic role of neuregulin 1 type III in SOD1-linked amyotrophic lateral sclerosis. Neurotherapeutics. 2020

\section{Publisher's Note}

Springer Nature remains neutral with regard to jurisdictional claims in published maps and institutional affiliations.

Ready to submit your research? Choose BMC and benefit from:

- fast, convenient online submission

- thorough peer review by experienced researchers in your field

- rapid publication on acceptance

- support for research data, including large and complex data types

- gold Open Access which fosters wider collaboration and increased citations

- maximum visibility for your research: over $100 \mathrm{M}$ website views per year

At BMC, research is always in progress.

Learn more biomedcentral.com/submissions 